\title{
Temporal Waterlogging and Physiological Performance of Wheat (Triticum aestivum L.) Seeds
}

\author{
Vânia M. Gehling ${ }^{1}$, Samantha R. Segalin ${ }^{1}$, Cristian Troyjack ${ }^{1}$, João R. Pimentel ${ }^{1}$, Ivan R. Carvalho ${ }^{1}$, \\ Vinícius J. Szareski ${ }^{1}$, Geison R. Aisenberg ${ }^{1}$, Ítala T. P. Dubal ${ }^{1}$, Francine Lautenchleger ${ }^{2}$, Velci Q. de Souza ${ }^{3}$, \\ Luis O. B. Schuch ${ }^{1}$, Emanuela G. Martinazzo ${ }^{4}$, Tiago Pedó ${ }^{1}$, Francisco A. Villela ${ }^{1} \&$ Tiago Z. Aumonde ${ }^{1}$ \\ ${ }^{1}$ Federal Universityof Pelotas, Campus Capão do Leão, Capão do Leão, RS, Brazil \\ ${ }^{2}$ StateUniversityof Londrina, Londrina, PR, Brazil \\ ${ }^{3}$ Federal Universityof the Pampa, Dom Pedrito, RS, Brazil \\ ${ }^{4}$ Federal University of Rio Grande, RS, Brazil \\ Correspondence: Ivan R. Carvalho, Universidade Federal de Pelotas, Campus Capão do Leão, CEP 96050-500, \\ Capão do Leão, RS, Brazil. E-mail: carvalho.irc@gmail.com
}

Received: March 12, 2018

doi:10.5539/jas.v10n6p363
Accepted: April 15, $2018 \quad$ Online Published: May 15, 2018

URL: https://doi.org/10.5539/jas.v10n6p363

\begin{abstract}
The aim of this work was to evaluate the physiological performance and some attributes of wheat seeds originated from plants submitted to soil flooding at different stages of development. The treatments consisted of periods of soil flooding, absence of flooding, two floods and three floods of the soil. Each flood lasted for three days. For the evaluation of the physiological quality, the seeds were submitted to the tests of germination and first germination count, germination speed index, shoot and primary root length, shoot and primary root dry matter mass, harvest index, thousand seed mass, electrical conductivity and isoenzymatic analysis. The increase of the soil flooding period did not affect germination, while the germination speed andindex, the harvest index and the thousand seed mass were lower in plants under the higher periods of soil flooding. The expression and intensity of bands of acid phosphatase and peroxidase isoenzymes were differently altered by periods of flooding. Thus, soil flooding negatively influences the physiological performance, the thousand seed mass and the harvest index when the plants are submitted to flooding of the soil.
\end{abstract}

Keywords: abiotic stress, flooding, isoenzymes, physiological quality

\section{Introduction}

Wheat (Triticum aestivum L.) belonging to the Poaceae family, is considered one of the main temperate climate crops grown during the winter. Annual national production ranges from 5 to 7 million tons of grains in the South (Rio Grande do Sul, Santa Catarina and Paraná), Southeast (Minas Gerais and São Paulo) and Midwest (Mato Grosso do Sul, Goiás and Distrito Federal) regions of Brazil. In Rio Grande do Sul, in 2017, more than 776 thousand hectares of wheat were cultivated, revealing the average yield of $3.214 \mathrm{~kg} \mathrm{~h}^{-1}$ and production of 2.49 million tons of grains. The wheat chain presents itself in deficit, becoming annual necessity of Brazil, the import superior than 3.0 million tons of grains. This situation is related to the consumption of grains, since it is estimated at 10.3 million tons (CONAB, 2017).

Brazil has about 28 million hectares of soils subject to waterlogging, and irrigated Oryza sativa crop is predominant in these soil conditions. Most of this area is kept in a fallow system or used for grazing, resulting in sub utilization for production (Gomes et al., 2006). In soils with such a characteristic, the air in the porous space is replaced by water, limiting gas exchange with the atmosphere (Sousa et al., 2010) and negatively affecting energy metabolism to reduce ATP synthesis (Van Dongen et al., 2011), and so can modify growth (Horzani et al., 2008; Szareski et al., 2016), the partition of assimilates (Pedó et al., 2016) and the yield of cultivated plants (Coelho et al., 2013).

Soil flooding promotes the activation of anaerobic metabolism and induces the production of toxic substances such as lactate and ethanol (Fante et al., 2010). The cultivation of some agricultural species under conditions of waterlogging or flooding of the soil can negatively influence the physiological quality of the seeds produced. 
Germination and vigor are attributes that define the physiological quality of the seeds and constitute responses of the reactivation of metabolism during imbibition (Peske et al., 2012).

Germination is evaluated under controlled conditions and allows the determination of viability and maximum germination potential of a seed lot, as determined under controlled environmental conditions (Peske et al., 2012; Carvalho et al., 2016). Therefore, vigor is related to more subtle characteristics of the physiological performance of the seeds and to the germination efficiency, which must be fast and uniform, regardless of the environmental condition (Szareski et al., 2017). Several tests can be used to determine the physiological performance of seeds, among them, cold test and accelerated aging, first germination count, germination speed index, seedling length and dry matter (Kehl et al., 2016; Szareski et al., 2016). In addition, isoenzymatic expression is an important tool for the determination of responses concerning the physiological performance of seeds (Troyjack et al., 2017; Soares et al., 2016; Pedó et al., 2016; Aisenberg et al., 2016; Monteiro et al., 2016; Dubal et al., 2016).

In view of the above, the present work had as objective to evaluate the physiological performance and some attributes of wheat seeds originated from plants submitted to soil flooding at different stages of development.

\section{Material and Mmethods}

The experiment was conducted in a chapel greenhouse, arranged in the north-south direction, located at latitude $31^{\circ} 48^{\prime} 15^{\prime \prime} \mathrm{S}$ and longitude 52 $24^{\prime} 55^{\prime \prime}$ W, Pelotas, Rio Grande do Sul, Brazil. The climate of this region is temperate with well distributed rains and hot summer, being of the type Cfa by the classification of Köppen.

The sowing of the Fundacep Bravo wheat cultivar was carried out in black polyethylene pots with a capacity of $14 \mathrm{~L}^{-1}$, filled with sifted soil and collected from the A1 horizon of a Solodic Eutrophic HaplicPlanosol, belonging to the Pelotas mapping unit (Strecket al., 2008). Fertilization and liming were performed according to previous soil analysis and as recommended by the Soil Chemistry and Fertility Commission, RS/SC (CQFS, 2004). For each experiment, four wheat plants per vase were maintained.

The experimental design was completely randomized, with six replicates. The treatments consisted of periods of soil flooding, where: $\mathrm{T} 1=$ no flooding (soil maintained in field capacity); $\mathrm{T} 2=$ soil submitted to two floods, the first being established in the vegetative phase at 45 days after emergence, during tillering and the second flood at 75 days after emergence, during booting phase; and T3 = soil submitted to three flood periods, the first being established in the vegetative phase at 45 days after emergence during tillering, the second flooding at 75 days after emergence during the booting phase and the third set at 116 days after the emergence during the seed filling stage.

In order to establish the treatments, the polyethylene pots containing soil were drilled in the lower part, thus facilitating drainage of excess water and maintenance of soil field capacity. The field capacity was determined from the tension table methodology (Embrapa, 1997), and by the field capacity definition, it was defined the volume of water required for the maintenance of the field capacity in the non-flooded treatment and for the establishment of the flood for a period of three days, and a $20 \mathrm{~mm}$ water blade was maintained on the surface of the soil through the fitting of a second black polyethylene vessel without perforations on the soil containing vessels, in order to avoid gas exchange. For the drainage of the soaked soil, the second vessel was removed to the perforated vessel and without perforations, allowing water to drain to the field capacity. The second vessel was not fitted in the T1 treatment.

At the end of the crop cycle, the plants were harvested, the seeds were separated manually and taken to the Seed Analysis Laboratory of the Plant Science Department of the EliseuMaciel Agronomy School, belonging to the Federal University of Pelotas, where the stationary drying took place in an oven, as recommended by Peske et al. (2012). Seed storage after the water content reduction process was carried out in a cold and dry chamber according to Baudet and Villela (2012). For the analysis of the yield and the physiological quality of the seeds, the following tests and evaluations were performed:

(a) Germination: carried out in six replicates with four subsamples of 50 seeds for each treatment. Seeding was performed on a paper substrate, previously moistened in distilled water in the proportion of two and a half times the mass of the paper and kept in a BOD type germinator at a temperature of $20^{\circ} \mathrm{C}$. The evaluations were carried out eight days after sowing, according to the Rules for Seed Analysis (Brazil, 2009), and the results are expressed as percentage of normal seedlings.

(b) First germination count: the number of normal seedlings, present at four days after sowing, at the germination test was evaluated, and the results are expressed in percentage (Brazil, 2009). 
(c) Germination speed index (GSI): obtained from daily germinated seeds counts (minimum radicular protrusion from 3 to $4 \mathrm{~mm}$ ). The counts were carried out until obtaining the constant number of germinated seeds, and GSI was obtained according to Nakagawa (1999).

(d) Germination speed: determined during the germination test, through daily germinated seed counts (minimum radius protrusion from 3 to $4 \mathrm{~mm}$ ). The results were expressed in days and determined according to Vieira and Carvalho (1994).

(e) Shoot and primary root length: were determined from four subsamples of 20 seedlings for each experimental unit. For this, the seeds were distributed disjointly in two longitudinal and parallel lines in the upper third of the Germitest germinating paper, moistened in proportion to two times and half their dry mass. The rolls of paper were packed in a BOD type chamber at a temperature of $20^{\circ} \mathrm{C}$. The growth data were measured eight days after sowing with a millimeter ruler, and the total length and shoot length of ten normal seedlings were measured. The shoot length was obtained by the distance between the insertion of the basal portion of the primary root to the apex of the aerial part, while the length of the primary root was measured by the distance between the apical and basal part of the primary root. The results were expressed in millimeters per seedling ( $\left.\mathrm{mm} \mathrm{seedling}^{-1}\right)$.

(f) Shoot and primary root dry matter mass: were obtained gravimetrically in a forced aeration oven at $70 \pm 2{ }^{\circ} \mathrm{C}$, until constant mass, measured in a precision analytical balance, the results being expressed in $\mathrm{mg}$ seedling ${ }^{-1}$.

(g) Harvest index: determined by the equation $\mathrm{Hi}=\mathrm{We} / \mathrm{Wt}$, where We corresponds to the dry mass of spikes and $\mathrm{Wt}$ is the total dry matter of the plant.

(h) Thousand seed mass: determined by counting eight replicates of 100 seed subsamples, whose mass was measured in precision analytical balance, according to Rules for Seed Analysis (Brazil, 2009). The results were expressed in grams.

(i) Electrical conductivity: the mass method was performed according to the general methodology proposed by the International Seed Testing Association (ISTA), and tested in different soaking periods ( 3,6 and 24 hours). For this, 50 seeds of each experimental unit had their mass measured and then were placed separately in polyethylene containers containing deionized water in the volume of $75 \mathrm{~mL}$, being kept at a temperature of 20-25 ${ }^{\circ} \mathrm{C}$. The readings were performed on the DM-32 Digimed model conductivity meter, and the results expressed in $\mu \mathrm{S} \mathrm{cm}^{-1} \mathrm{~g}^{-1}$ of seeds.

(j) Isoenzymes: seedlings obtained by the collection of ten plant units, from the germination test, were used eight days after sowing, as indicated by the Rules for Seed Analysis (Brazil, 2009). The seedlings were macerated separately in porcelain mortar in an ice bath. Then, $200 \mathrm{mg}$ of the macerate from each sample were transferred to microcentrifuge tubes and added with $0.2 \mathrm{M}$ lithium borate solution at $\mathrm{pH} 8.3+$ Tris Citrate $+0.2 \mathrm{M}(\mathrm{pH} 8.3)+$ $0.15 \%$ of 2 -mercaptoethanol in the ratio $1: 2(\mathrm{~m} / \mathrm{v})$. Electrophoresis was performed on $7 \%$ polyacrylamide gels, applying $20 \mu \mathrm{L}$ of each sample. The staining systems used are described by Scandálios (1969) and Alfenas (1998). The expression of esterase isoenzymes, acid phosphatase and peroxidase were determined by the vertical polyacrylamide gel electrophoresis system (Malone et al., 2007).

The data were analyzed for normality and homoscedasticity and later submitted to the analysis of variance by the $\mathrm{F}$ test. Having significance, the data were compared by the Tukey test at $5 \%$ of probability.

\section{Results and Discussion}

For the variable germination, no significant effect was observed as a function of the different evaluated treatments. However, for the first germination count, it was observed that the treatments corresponding to the absence of flooding and the three floods, Resulted in a higher percentage of normal seedlings compared to the treatment with two floods (Table 1). The similarity between seed germination in all treatments may be related to the similar accumulation of reserve compounds (Sairam et al., 2009). These responses may be related to the effect of soil flooding, because this stress causes a reduction in the supply of mineral nutrients to the aerial part, besides inducing free radical formation (Bailey-Serres \& Voesenek, 2008; Colmer \& Greenway, 2011), which at high concentrations are detrimental to plant development.

The germination speed index was higher when there was no soil flooding, and did not differ between seeds originating from plants under the action of two and three soil floods (Table 1). For the germination speed, plants under the effect of two and three floods did not differ from each other and presented higher results than those without soil flooding. The reduction of the germination speed index indicates a reduction in the number of germinated seeds per day and thus less vigor of these species' perpetuation structures. According to Sairam et al. (2009), prolonged soil flooding leads to oxidative stress and unbalance of different metabolic pathways, influencing the development of distinct cell structures and mechanisms in the seed maturation process. When the 
maturation process is negatively influenced, the physiological quality and expression of seed vigor tend to be reduced.

Soil flooding is one of the major abiotic stresses responsible for reduced growth and can affect plant development (Strauss et al., 2007). In this sense, it may affect the initial establishment of the crops, reduce the photosynthesis and the translocation of photoassimilates (Parent et al., 2008).

The shoot length had no significant effect, whereas the primary root length was higher in wheat seedlings under the influence of three and two soil floods, respectively (Table 1). However, the lowest primary root length was observed in seedlings maintained at field capacity.

Table 1. First germination count (FGC), germination speed index (GSI), germination speed (GS) and primary root length $\left(\mathrm{R}_{\mathrm{L}}\right)$ in wheat seeds originated from plants submitted to different periods of soil flooding, Capão do Leão, RS

\begin{tabular}{lllll}
\hline Treatment & FGC (\%) & GSI & GS & $\mathrm{R}_{\mathrm{L}}(\mathrm{mm})$ \\
\hline No flooding $\left(\mathrm{FC}^{* *}\right)$ & $88.0 \mathrm{a}^{*}$ & $46.83 \mathrm{a}$ & $1.06 \mathrm{~b}$ & $111.65 \mathrm{c}$ \\
Twofloods & $79.0 \mathrm{~b}$ & $44.33 \mathrm{~b}$ & $1.14 \mathrm{a}$ & $122.88 \mathrm{~b}$ \\
Threefloods & $85.0 \mathrm{a}$ & $45.03 \mathrm{~b}$ & $1.12 \mathrm{a}$ & $131.9 \mathrm{a}$ \\
\hline C.V. $(\%)$ & 3.60 & 1.70 & 1.50 & 3.50 \\
\hline
\end{tabular}

Note. ${ }^{*}$ Means followed by the same letter in the column do not differ by Tukey test $(\mathrm{p} \leq 0.05) .{ }^{* *} \mathrm{FC}=$ field capacity.

For shoot and root dry matter, those from seedlings originated from plants exposed to three floods of the soil, reached higher values when compared to those from plants not exposed to flooding and exposed to two floods in the soil, which did not differ significantly (Table 2).

It is observed that the flooding of the soil did not affect the capacity of dry matter allocation in seedlings. It is known that some plants can overcome the stress period and for this they need a recovery period (Colmer \& Greenway, 2011). As the plants were subjected to soil flooding during the vegetative period and grain filling, it is possible that the three day flooding time was not able to provide irreversible damage to the physiological quality of wheat seeds in terms of mass and length. However, the recovery of the plant after flooding stress is related as the stage of development in which stress occurs and with stress intensity (Fries et al., 2007; Bailey-Serres \& Voesenek, 2008), or with sensitivity of the genotype.

Harvest index was higher for plants maintained in the absence of soil flooding, compared to plants under two and three soil floods, which did not differ (Table 2). The thousand seed mass also presented superiority when the wheat plants were maintained in the field capacity, followed by those exposed to two floods and three floods of the soil, respectively.

The lower harvest index corroborates the lower thousand seed mass of plants submitted to soil flooding. The lowest harvest index allows to observe reduced seed dry matter allocation compared to the amount incorporated in the rest of the plants. At the same time, the lower thousand seed mass allows to observe the smaller amount of assimilates deposited in seeds of plants under soil flooding, comparatively to those maintained in the field capacity.

Soil flooding affects the yield of upland species, mainly due to the low availability of oxygen in the roots, responsible for a series of metabolic alterations (Horchani et al., 2009), such as the reduction in energy production (Horchani et al., 2009), such as the reduction in energy production (Horchani et al., 2009; Zabalza et al., 2009). In plants under soil flooding, reductions in nutrient absorption and photosynthesis may occur (Batista et al., 2008), decrease in leaf chlorophyll content, early leaf senescence and leaf area reduction (Parent et al., 2008). For corn plants subjected to soil flooding, there is a reduction in grain yield (Lone \& Warsi, 2009). 
Table 2. Shoot $\left(\mathrm{W}_{\mathrm{S}}\right)$ and seedling roots $\left(\mathrm{W}_{\mathrm{R}}\right)$ dry matter, harvest index $\left(\mathrm{H}_{\mathrm{i}}\right)$ and thousand seed mass $\left(\mathrm{M}_{1000}\right)$ of wheat originated from plants submitted to different periods of soil flooding, Capão do Leão, RS

\begin{tabular}{lllll}
\hline Treatment & $\mathrm{W}_{\mathrm{S}}(\mathrm{mg})$ & $\mathrm{W}_{\mathrm{R}}(\mathrm{mg})$ & $\mathrm{H}_{\mathrm{i}}$ & $\mathrm{M}_{1000}(\mathrm{~g})$ \\
\hline No flooding $\left(\mathrm{FC}^{* *}\right)$ & $4.5 \mathrm{~b}^{*}$ & $6.08 \mathrm{~b}$ & $0.44 \mathrm{a}$ & $36.33 \mathrm{a}$ \\
Twofloods & $4.42 \mathrm{~b}$ & $6.5 \mathrm{~b}$ & $0.35 \mathrm{~b}$ & $35.33 \mathrm{~b}$ \\
Threefloods & $4.98 \mathrm{a}$ & $7.37 \mathrm{a}$ & $0.34 \mathrm{~b}$ & $30.75 \mathrm{c}$ \\
\hline C.V. $(\%)$ & 4.80 & 5.30 & 7.40 & 1.40 \\
\hline
\end{tabular}

Note. ${ }^{*}$ Means followed by the same letter in the column do not differ by Tukey test $(\mathrm{p} \leq 0.05) .{ }^{* *} \mathrm{FC}=$ field capacity.

The electrical conductivity of seeds originated from plants maintained in the field capacity, regardless of the imbibition time, was higher in relation to those from exposed plants and to three floods in the soil (Table 3). The higher electrical conductivity is indicative of a higher amount of extravasated electrolytes, of the lower capacity of reorganization of the cell membranes system and allows to infer that the higher the electrical conductivity, the lower the seed vigor (Araujo et al., 2011; Zimmer, 2012).

Table 3. Electric conductivity of wheat seeds from plants submitted to different periods of soil flooding, after 3; 6 and 24 h of imbibition, Capão do Leão, RS

\begin{tabular}{llll}
\hline \multirow{2}{*}{ Treatment } & \multicolumn{3}{c}{ Conductivity $\left(\mu \mathrm{S} \mathrm{cm}^{-1} \mathrm{~g}^{-1}\right)$} \\
\cline { 2 - 4 } & $3 \mathrm{~h}$ & $6 \mathrm{~h}$ & $24 \mathrm{~h}$ \\
\hline No flooding $\left(\mathrm{FC}^{* *}\right)$ & $24.90 \mathrm{a}^{*}$ & $26.13 \mathrm{a}$ & $38.35 \mathrm{a}$ \\
Twofloods & $18.12 \mathrm{~b}$ & $19.16 \mathrm{~b}$ & $30.05 \mathrm{~b}$ \\
Threefloods & $15.64 \mathrm{~b}$ & $17.01 \mathrm{~b}$ & $28.16 \mathrm{~b}$ \\
\hline C.V. $(\%)$ & 10.7 & 10.6 & 10.4
\end{tabular}

Note. * Means followed by the same letter in the column do not differ by Tukey test $(\mathrm{p} \leq 0.05) .{ }^{*}$ FC $=$ field capacity.

As observed, the thousand seed mass was higher in seeds produced by plants not exposed to soil flooding (Table 2). However, the highest dry matter allocation was observed in seedlings produced from seeds produced under the influence of three floods in the soil. It is possible that the higher allocation of dry matter in seedlings produced by seeds under the longest flooding period is related to the greater efficiency of the reorganization process in the cell membranes system, contributing to the lower loss of reserves stored in the endosperm.

The isozyme esterase expression was altered in seedlings under two periods of soil flooding (Figure 1A). Under this period, there was an increase in the number of bands compared to seedlings under the influence of three periods of soil flooding and to those maintained at field capacity, which were less intense, respectively. The intensity and expression of acid phosphatase isoenzyme bands were higher in the seedlings under effect of field capacity (Figure 1B). And, the peroxidase altered its expression in relation to the number and intensity of the bands with the increase of the soil flooding period, not occurring expression in seedlings maintained in the field capacity (Figure 1C). 

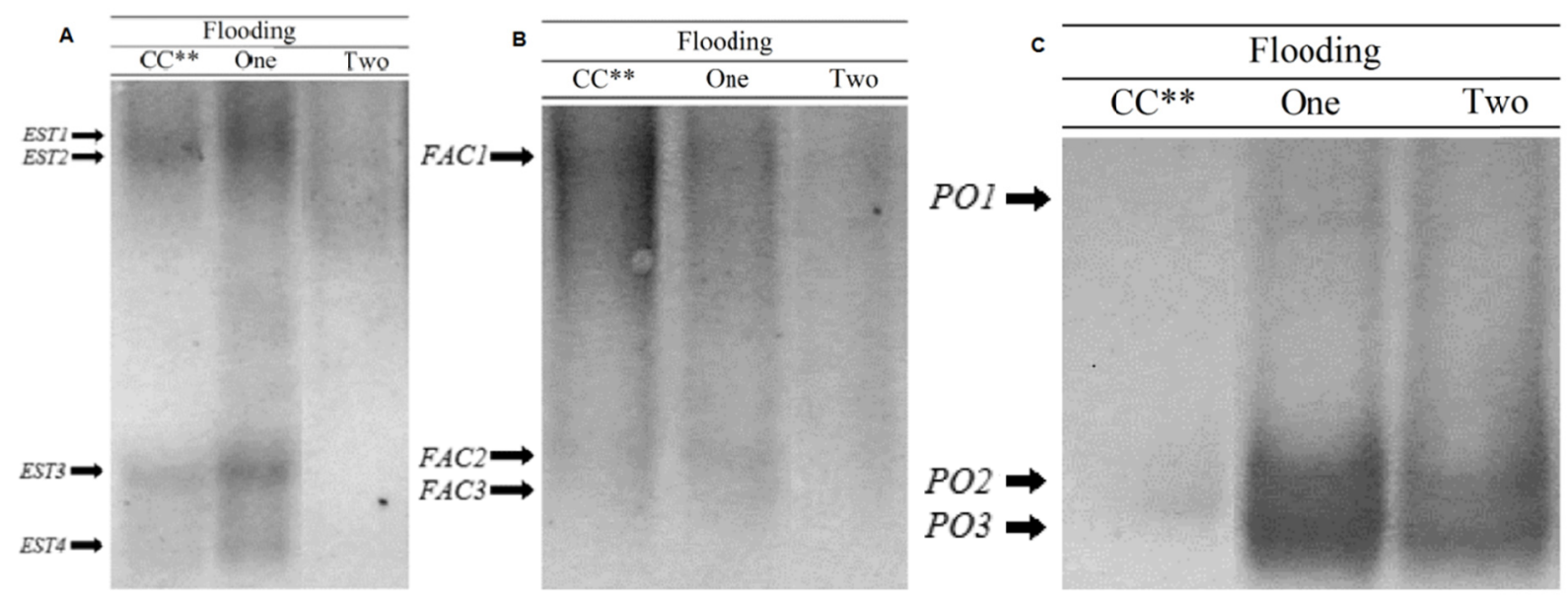

Figure 1. Isoenzymatic expression in wheat seedlings originated from plants submitted to different periods of soil flooding, where: Esterase (a), Acid phosphatase (b) and Peroxidase (c). ${ }^{* *} \mathrm{FC}=$ field capacity; Two = two periods of flooding; Three $=$ three periods of flooding, Capão do Leão, RS

Gene expression, enzyme synthesis and plant defense mechanisms are fundamental for seedling growth in response to stress conditions (Frieset et al., 2007). The esterase can act on membrane phospholipids in seeds (Santos et al., 2005) and reflect in reduction of vigor. On the other hand, acid phosphatase participates in the ester hydrolysis, it can act on the cellular membrane system and affect the respiratory activity by the peroxidation of unsaturated lipids in the mitochondrial membranes, a fact that is related to the deterioration process in seeds. On the other hand, peroxidase enzymes are proteins associated with physiological and biochemical processes in response to stresses during growth (Matamoros et al., 2003; Jebara et al., 2005).

As a result, the analysis of the data allowed to verify that the periods of soil flooding reduced the vigor and yield of the wheat seeds, as verified in the tests of first germination count, germination speed index, germination speed, affecting negatively the dry matter allocation, the harvest index and the thousand seed mass. In addition, it is possible to observe that flooding modified the isozyme expression patterns in electrophoretic systems.

\section{Conclusion}

The physiological performance is negatively influenced by soil flooding, occurring a reduction of the thousand seed mass and the harvest index when the plants are submitted to said stress; the increase of the flooding periods of the soil negatively influences the germination speed index of wheat seeds, indicating reduction of vigor.

\section{References}

Aisenberg, G. R., Zimmer, G., Koch, F., Dellagostin, S. M., Szareski, V. J., Carvalho, I. R., ... Aumonde, T. Z. (2016). Biochemical performance, vigor and characteristics of initial growth of wheat plants under different sowing depths. International Journal of Current Research, 8(8), 36704-36709.

Alfenas, A. C. (1998). Eletroforese de isoenzimase proteinas afins (p. 574). Viçosa: UFV.

Araujo, R. F., Zonta, J. B., Araújo, E. F., Donzeles, S. M. L., \& Costa, G. M. (2011). Teste de condutividade elétrica para sementes de feijão-mungo-verde. Revista Brasileira de Sementes, 33, 123-130. https://doi.org/ $10.1590 / \mathrm{S} 0101-31222011000100014$

Bailey-Serres, J., \& Voesenek, L. A. C. J. (2008). Flooding stress: Acclimation and genetic diversity. Annual Review of Plant Biology, 59, 313-319. https://doi.org/10.1146/annurev.arplant.59.032607.092752

Batista, C. U. N., Medri, M. E., Bianchini, E., Medri, C., \& Pimenta, J. A. (2008). Tolerância à inundação deCecropiapachystachyaTrec. (Cecropiaceae): Aspectos ecofisiológicos e morfoanatômicos. Acta Botânica Brasileira, 22, 91-98. https://doi.org/10.1590/S0102-33062008000100012

Baudet, L. M., \& Villela, F. A. (2012). Armazenamento de sementes. In S. T. Peske, F. A. Villela, \& G. E. Meneguello (Eds.), Sementes: Fundamentos Científicos e Tecnológicos (Vol. 3, pp. 481-527).

Brasil. (2009). Regras para análise de sementes (p. 395). Brasília: Secretaria de Defesa Agropecuária/MAPA (Ministério da Agricultura, Pecuáriae Abastecimento)/ACS. 
Carvalho, I. R. (2016). Sowing date and multivariate analysis of yield and physiological components in elite wheat genotypes. International Journal of Current Research, 8, 40828-40833.

Coelho, C. C. R., Neves, M. G., de Oliveira, L. M., da Conceição, A. G. C., Okumura, R. S., \& de Oliveira Neto, C. F. (2013). Biometria em plantas de milho submetidas ao alagamento. Agroecossistemas, 5, 32-38. https://doi.org/10.18542/ragros.v5i1.1408

Colmer, T. D., \& Greenway, H. (2011). Ion transport in seminal and adventitious roots of cereals during $\mathrm{O}_{2}$ deficiency. Journal of Experimental Botany, 62, 39-57. https://doi.org/10.1093/jxb/erq271

CONAB. (2017). Acompanhamento da safra brasileira de grãos v. 4-SAFRA 2016/17, Sexto levantamento (p. 176).

CQFS-RS/SC (Comissãode Químicae Fertilidadedo Solo RS/SC). (2004). Manual de adubação e de calagem para o Estado do Rio Grande do Sul e Santa Catarina (p. 400). Porto Alegre, SBCS/Núcleo Regional Sul, UFRGS.

Dubal, I. T. P., Troyjack, C., Aisenberg, G. R., Koch, F., Szareski, V. J., Pimente, J. R., ... Pedó, T. (2016). Effect of temperature on bean seed germination: Vigor and isozyme expression. Agricultural Science Research Journals, 1, 001-009.

Embrapa (Empresa Brasileira de Pesquisa Agropecuária). (1997). Manual de métodos de análise de solo (2nd ed., p. 212). Rio de Janeiro: EMBRAPA-CNPS.

Fante, C. A., Alves, J. D., Pereiragoulart, P. de F., Deuner, S., \& Silveira, N. M. (2010). Respostas fisiológicas em cultivares de soja submetidas ao alagamento em diferentes estádios. Bragantia, 69, $253-261$. https://doi.org/10.1590/S0006-87052010000200001

Fries, D. D., Alves, J. D., Filho, N. D., \& Magalhães, M. M. (2007). Crescimento de plântulas do milho "saracura" e atividade de $\alpha$-amilase e invertases associados ao aumento da tolerância ao alagamento exercido pelo cálcio exógeno. Bragantia, 66, 1-9. https://doi.org/10.1590/S0006-87052007000100001

Gomes, A. S., Silva, C. A. S. D., Parfit, J. M. B., Pauletto, E. A., \& Pinto, L. F. S. (2006). Caracterização de indicadores da qualidade do solo, com ênfase às áreas de várzea do Rio Grande do Sul (p. 40). Pelotas: Embrapa Clima Temperado.

Horchani, F., Khayati, H., Raymond, P., Brouquisse, R., \& Aschi-Smiti, S. (2009). Contrasted effects of prolonged root hypoxia on tomato root and fruit (Solanum lycopersicum) metabolism. Journal of Agronomy and Crop Science, 195, 313-318. https://doi.org/10.1111/j.1439-037X.2009.00363.x

ISTA (International Seed Testing Association). (1995). Handbook of vigour test methods (3rd ed., p. 117).

Jebara, S., Jebara, M., Limam, F., \& Aouani, M. E. (2005). Changes in ascorbate peroxidase, catalase, guaiacol peroxidase and superoxide dismutase activities in common bean (Phaseolus vulgaris) nodules under salt stress. Journal of Plant Physiology, 162, 929-936. https://doi.org/10.1016/j.jplph.2004.10.005

Kehl, K., Kehl, K., Aisenberg, G. R., Koch, F., Monteiro, M. A., Szareski, V. J., ... Aumonde, T. Z. (2016). Plant pre harvest desiccation and phisiological performance of wheat seeds before and after storage. International Journal of Current Research, 8, 38456-38460.

Lone, A. A., \& Warsi, M. Z. K. (2009). Response of maize (Zea mays L.) to excess soil moisture (ESM) tolerance at different stages of life cycle. Botany Research International, 2, 211-217.

Malone, G., Zimmer, P. D., Meneghello, G. E., Castro, M. A. D. S. D., \& Peske, S. T. (2007). Expressão diferencial de isoenzimas durante o processo de germinação de sementes de arroz em grandes profundidades de semeadura. Revista Brasileira de Sementes, 29, 61-67. https://doi.org/10.1590/S0101-312 22007000100009

Matamoros, M. A., Dalton, D. A., Ramos, J., Clemente, M. R., Rubio, M. C., \& Becana, M. (2003). Biochemistry and molecular biology of antioxidants in therhizobia-legume symbiosis. Plant Physiology, 133, 499-509. https://doi.org/10.1104/pp.103.025619

Monteiro, M. A., Aisenberg, G. R., Koch, F., Salau, G. M., Behenck, J. P. de O., Demari, G. H., ... Aumonde, T. Z. (2016). Yield and vigor of corn seeds under the influence of flooding periods. African Journal of Agricultural Research, 11, 3240-3245. https://doi.org/10.5897/AJAR2016.11367

Nakagawa, J. (1999). Testes de vigor baseados no desempenho das plântulas. In F. C. Krzyzanoswki, R. D. VIeira, \& J. B. França Neto (Eds.), Vigor de sementes: conceitos e testes (2: 1-2.24). Londrina: ABRATES. 
Parent, C., Nicolas, C., Audrey, B., Crevècoeur, M., \& Dat, J. (2008). An overview of plant responses to soil waterlogging. Plant Stress, 2, 20-27.

Pedó, T., Aisenberg, G. R., Martinazzo, E. G., de Souza, V. Q., Pedroso, C. E. da S., \& Aumonde, T. Z. (2016). Soil waterlogging during late season: Growth, assimilate partitioning and vigor of bean seeds. African Journal of Agricultural Research, 11, 805-811. https://doi.org/10.5897/AJAR2015.10481

Pedo, T., Koch, F., Delias, D. dos S., Aisenberg, G. R., Szareski, V. J., Carvalho, I. R., \& Aumonde, T. Z. (2016). Antioxidante enzyme activity and initial growth of wheat, rye and bean under soil flooding. International Journal of Current Research, 8(8), 36635-36642.

Peske, S. T., Villela, F. A., \& Meneghello, G. E. (2012). Sementes: Fundamentos Científicos e Tecnológicos (3rd ed., p. 573). Pelotas, UFPel.

Sairam, R. K., Dharmar, K., Chinnusamy, V., \& Meena, R. C. (2009). Waterlogging-induced increase in sugar mobilization, fermentation, and related gene expression in the roots of mung bean (Vigna radiata). Journal of Plant Physiology, 166, 602-616. https://doi.org/10.1016/j.jplph.2008.09.005

Santos, C. M. R., De Menezes, N. L., \& Villela, F. A. (2005). Modificações físiológicas e bioquímicas em sementes de feijão no armazenamento. Revista Brasileira de Sementes, 27, 104-114. https://doi.org/ 10.1590/S0101-31222005000100013

Scandálios, J. G. (1969). Genetic control of multiple molecular forms of enzymes in plants: A review. Biochemical Genetics, 3, 37-79. https://doi.org/10.1007/BF00485973

Soares, V. N., Szareski, V. J., Nardino, M., \& Souza, V. Q. D. (2016). Stress due to soil flooding and differential plysiological responses to initial growht of wheat plants. Australian Journal of Basic and Applied Sciences, 10, 260-266.

Sousa, R., Camargo, F. A. O., \& Vahl, L. C. (2010). Solos alagados: (Reações de redox). In E. J. Meurer (Ed.), Fundamentos de química do solo (pp. 171-195). Porto Alegre: Evangraf.

Strauss, A. J., KrãGer, G. H., Strasser, R. J., \& van Heerden, P. D. (2007). The role of low soil temperature in the inhibition of growth and PSII function during dark chilling in soybean genotypes of contrasting tolerance. Physiologia Plantarum, 131, 89-105. https://doi.org/10.1111/j.1399-3054.2007.00930.x

Streck, E. V., Kampf, N., Dalmolin, R. S. D., Klamt, E., Nascimento, P. C. do, Schneider, P., ... Pinto, L. F. S. (2008). Solos do Rio Grande do Sul (2nd ed., p. 222). Porto Alegre: EMATER/RS; UFRGS.

Szareski, V. J. et al. (2016). Seeding rate and physiological quality of dual purpose wheat seeds. AfricanJournal of Agricultural Research, 11(43), 4367-4374. https://doi.org/10.5897/AJAR2016.11578

Szareski, V. J., Carvalho, I. R., Kehl, K., Levien, A. M., Nardino, M., Demari, G. H., ... Aumonde, T. Z. (2017). Univariate, multivariate techniques and mixed models applied to the adaptability and stability of wheat in the Rio Grande do Sul State. Genetics and Molecular Research, 16(3), 1-13. https://doi.org/10.4238/gmr160 39735

Szareski, V. J., Carvalho, I. R., Nardino, M., Henrique Demari, G., Pelegrin, A. J. de, Ferrari, M., ... Aumonde, T. Z. (2016). Ethyl Methane Sulfonate and its effects on morphological traits of dual-pourpose wheat. International Journal of Current Research, 8(10), 39707-39713.

Troyjack, C., Dubal, I. T. P., Felipe, K., Vinicius Jardel, S., Joao Roberto, P., Carvalho, I. R., ... Pedo, T. (2017). Attributes of growth, physiological quality and isoenzymatic expression of common bean seeds produced under the effect of gibberellic acid. Aust J Crop Sci, 11, 1116-1122. https://doi.org/10.21475/ajcs.17.11. 09.pne531

Van Dongen, J. T., Gupta, K. J., Ramírez-Aguilar, S. J., Araújo, W. L., Nunes-Nesi, A., \& Fernie, A. R. (2011). Regulation of respiration in plants: A role for alternative metabolic pathways. Journal of Plant Physiology, 168, 1434-1443. https://doi.org/10.1016/j.jplph.2010.11.004

Vieira, R. D., \& Carvalho, N. M. (1994). Testes de vigor em sementes (p. 164). Jaboticabal: FUNEP.

Zabalza, A., Van Dongen, J. T., Froehlich, A., Oliver, S. N., Faix, B., Gupta, K. J., ... Geigenberger, P. (2009). Regulation of respiration and fermentation to control the plant internal oxygen concentration. Planthysiology, 149, 1087-1098.

Zimmer, P. D. (2012). Fundamentos da qualidade de sementes. In S. T. Peske, F. A. Villela, \& G. E. Meneghello (Eds.), Sementes: Fundamentos Científicos e Tecnológicos (3rd ed., pp. 106-160). Pelotas, UFPel. 


\section{Copyrights}

Copyright for this article is retained by the author(s), with first publication rights granted to the journal.

This is an open-access article distributed under the terms and conditions of the Creative Commons Attribution license (http://creativecommons.org/licenses/by/4.0/). 